\title{
The Relationship between Xanthine Oxidoreductase and Xanthine Oxidase Activities in Plasma and Kidney Dysfunction
}

\author{
Hiroyuki Terawaki ${ }^{1,5^{*}}$, Takayo Murase ${ }^{3}$, Aya Nakajima ${ }^{1}$, Keiko Aoyagi ${ }^{1}$, Naotaro Fukushima ${ }^{1}$, \\ Yoshihiro Tani ${ }^{2}$, Takashi Nakamura ${ }^{4}$ and Junichiro James Kazama ${ }^{2}$ \\ ${ }^{1}$ Dialysis Center, Fukushima Medical University, Fukushima, Japan \\ ${ }^{2}$ Department of Nephrology and Hypertension, Fukushima University, Fukushima, Japan
}

${ }^{3}$ Radioisotope and Chemical Analysis Center, Sanwa Kagaku Kenkyusho Co., Ltd., Mie, Japan

${ }^{4}$ Pharmacological Study Group, Pharmaceutical Research Laboratories, Sanwa Kagaku Kenkyusho Co., Ltd., Mie, Japan

${ }^{5}$ Department of Internal Medicine, Nephrology, Teikyo University Chiba Medical Center, Chiba, Japan

*Corresponding Author: Hiroyuki Terawaki, Department of Internal Medicine, Nephrology, Teikyo University Chiba Medical Center, Anesaki, Ichihara City, Japan, Tel: +81-436-62-1211, FAX: +81-436-562-7340; E-mail: terawaki@med.teikyo-u.ac.jp

Received date: March 21, 2017; Accepted date: March 27, 2016; Published date: March 31, 2017

Citation: Terawaki H, Murase T, Nakajima A, Aoyagi K, Fukushima N, et al. (2017) The Relationship between Xanthine Oxidoreductase and Xanthine Oxidase Activities in Plasma and Kidney Dysfunction. J Clin Exp Nephrol 1: 31. doi: 10.21767/2472-5056.100031

Copyright: (c) 2017 Terawaki $\mathrm{H}$, et al. This is an open-access article distributed under the terms of the Creative Commons Attribution License, which permits unrestricted use, distribution, and reproduction in any medium, provided the original author and source are credited.

\section{Abstract}

Background: Oxidative stress (OS) is thought to play a role in detrimental events among patients with chronic kidney disease (CKD). Although the mechanism of OS increases in CKD patients is unclear, it has been suggested that increased activity of xanthine oxidase (XO), the superoxideproducing form of xanthine oxidoreductase (XOR), plays a large role in enhancing OS. Therefore, we measured the activities of plasma XOR and XO among CKD patients.

Methods: Thirteen CKD patients were enrolled in this study. Their plasma XOR and XO activities were measured using a liquid chromatography-triple quadrupole mass spectroscopy (LC-TQMS) method, and the ratio of XO to XOR (XO/XOR) was calculated.

Results: The XOR and XO activities (pmol/h/mL plasma) were $8.30-58.2$ and $9.15-40.8$, and $X O / X O R$ value was $0.698-1.240$. Both XOR and XO showed positive correlation with estimated glomerular filtration rate (eGFR) $(R=0.751$, $\mathrm{P}=0.0020$ and $\mathrm{R}=0.773, \mathrm{P}=0.0031$, respectively). On the other hand, $\mathrm{XO} / \mathrm{XOR}$ showed negative correlation with eGFR ( $\mathrm{R}=-0.614, \mathrm{P}=0.0236)$

Conclusion: $X O R$ and $X O$ activities are decreased, and $\mathrm{XO} / \mathrm{XOR}$ ratio is increased, in accordance with renal dysfunction. High XO/XOR ratio in advanced CKD patients might contribute to the elevation of OS.

Keywords: Chronic kidney disease; Endothelium; Oxidative stress; Xanthine oxidase; Xanthine oxidoreductase

\section{Introduction}

Renal dysfunction is an independent risk factor for death and/or cardiovascular disease (CVD) events among the general population $[1,2]$. Although the reason why renal dysfunction increases CVD mortality and morbidity is unclear, the accumulated evidence suggests the major participation of oxidative stress (OS) [3]. Among patients with chronic kidney disease (CKD), OS increases in correlation with renal dysfunction [4], and enhanced OS among CKD patients induces an increase of CVD mortality and morbidity [5]. Such OS is widely considered as therapeutic target [6].

On the other hand, the participation of increased activity of xanthine oxidase $(\mathrm{XO})$ on enhanced OS has been suggested [7]. $\mathrm{XO}$ is one of the isoforms of xanthine oxidoreductase (XOR, EC 1.2.3.2), which is known as a house-keeping enzyme. $X O R$ is found as xanthine hydrogenase (XDH) in almost all living things, including bacteria, plants, eumycetes, and animals, while only mammals have both the XDH and XO forms [8]. XDH and XO are single-gene products [9] that catalyze the oxidation of hypoxanthine to xanthine and xanthine to uric acid; however, these two forms utilize different electron acceptors. Namely, $\mathrm{XDH}$ utilizes nicotinamide adenine dinucleotide (NAD+) and does not produce reactive oxygen species (ROS), whereas XO utilizes oxygen and generates ROS such as superoxide anion radicals and hydrogen peroxide. Accordingly, an increase in the XO/XOR ratio could accelerate OS via ROS generation.

Sakuma et al. reported that XDH $\rightarrow$ XO conversion is caused by disulfide compounds via reversible or non-reversible oxidation of thiol group in XDH [10]. Because thiol oxidation of serum albumin is enhanced in correlation with kidney dysfunction [4], plasma XO/XOR, which reflects XO/XOR of the capillary endothelium [11], might also be increased among advanced CKD patients. Moreover, no existing studies have 
examined the relationship between plasma XOR or XO activity and renal function, for XOR activity is very low in healthy human and thus its precise measurement had been difficult $[12,13]$.

The aim of this study is to evaluate the relationship between plasma XOR, XO and renal function.

\section{Material and Methods}

Thirteen predialysis CKD patients at Fukushima Medical University Hospital (Fukushima, Japan) were enrolled in the study. The patients' profiles including underlying kidney disease are shown in Table 1. No patient had received antioxidant agents such as ascorbic acid or vitamin E. Patients on corticosteroid therapy and those with malignancy were excluded from this study.

Physical measurements including height, weight, and blood pressure were taken, and then blood samples were collected to measure XOR and XO activities; $2 \mathrm{~mL}$ was drawn from the plasma obtained by centrifugation at $4^{\circ} \mathrm{C}$ immediately after the blood sampling from each patient, and stored at $-80^{\circ} \mathrm{C}$ for $2-6$ weeks until analysis. In addition, serum creatinine and C-reactive protein level, and plasma level of XOR substrates (hypoxanthine, xanthine and uric acid) were measured. As a marker of renal function, the estimated glomerular filtration rate (eGFR) was calculated by the CKD-EPI equation modified for Japanese using Japanese coefficient [14].

Measurement of XOR and XO activities was performed by the method previously reported by Murase et al. using liquid chromatography combined with triple quadrupole mass spectrometry (LC-TQMS method) [15]. Briefly, specimens were purified by Sephadex G25 column and were added to Tris buffer $\left(\mathrm{pH}\right.$ 8.5) containing $\left[{ }^{13} \mathrm{C}_{2},{ }^{15} \mathrm{~N}_{2}\right]$ xanthine, NAD+, and $\left[{ }^{13} \mathrm{C}_{3},{ }^{15} \mathrm{~N}_{3}\right]$ uric acid. These mixtures were incubated at $37^{\circ} \mathrm{C}$ for $90 \mathrm{~min}$. Subsequently, the mixtures were treated and the production levels of $\left[{ }^{13} \mathrm{C}_{2},{ }^{15} \mathrm{~N}_{2}\right]$ uric acid were measured using liquid chromatography (NANOSPACE SI-2, Shiseido)-triple quadrupole mass spectrometer (TSQ-Quantum, Thermo Fisher Scientific) (LC-TQMS). XO activity was determined by measuring $\left[{ }^{13} \mathrm{C}_{2},{ }^{15} \mathrm{~N}_{2}\right]$ uric acid formation in the absence of NAD+. XOR and $\mathrm{XO}$ activities were expressed as $\left[{ }^{13} \mathrm{C}_{2},{ }^{15} \mathrm{~N}_{2}\right]$ uric acid in $\mathrm{pmol} / \mathrm{h} / \mathrm{mL}$ plasma. All measurements were duplicated and the mean values were adapted for the evaluation. Based on the XOR and $X O$ activities obtained using the procedures described above, the ratio of XO to XOR (XO/XOR) was calculated.

Substrates of XOR (hypoxanthine, xanthine and uric acid) were measured using LC/MS method. Other biochemical tests were measured using standard laboratory techniques.

Values were expressed as means \pm standard deviation unless otherwise stated. We used the statistical software Stat View 9.3 (SAS Institute Inc., Cary, NC, USA). To determine the magnitude of the correlation, we used Pearson's correlation coefficient (R). Item-category data (gender, primary disease, prescription, past history) were introduced into the analysis as dummy variables. The correlation was determined to be significant when the $p$ value was less than $0.05(5 \%)$ with Fisher's Z transformation.
The study was performed according to the principles of the Declaration of Helsinki and was approved by the local ethics committee (Fukushima Medical University, approval no. 2349). All subjects provided their written informed consent.

Table 1: Patient characteristics.

\begin{tabular}{|c|c|}
\hline Age years & $62.1 \pm 18.8$ \\
\hline Gender \%male & 53.8 \\
\hline $\mathrm{BMI} \mathrm{kg/m2}$ & $24.2 \pm 4.3$ \\
\hline \multicolumn{2}{|l|}{ Primary CKD n } \\
\hline Chronic glomerulonephritis & 9 \\
\hline Nephrosclerosis & 2 \\
\hline Polycystic kidney & 1 \\
\hline Others & 1 \\
\hline History of cardiovascular disease \% & 7.7 \\
\hline Antihypertensive medication \% & 84.6 \\
\hline Usage of erythrocyte-stimulating factor $\%$ & 15.4 \\
\hline Usage of xanthine-oxidoreductase inhibitor \% & 61.5 \\
\hline a) None $n$ & 5 \\
\hline b) Febuxostat $n$ & 5 \\
\hline c) Topiroxostat $n$ & 1 \\
\hline d) Allopurinol $n$ & 2 \\
\hline \multicolumn{2}{|l|}{ Blood pressure $\mathrm{mmHg}$} \\
\hline Systolic & $136 \pm 22$ \\
\hline Diastolic & $84 \pm 6$ \\
\hline Estimated glomerular filtration rate $\mathrm{mL} / \mathrm{min} / 1.73 \mathrm{~m}^{2}$ & $42.7 \pm 23.4$ \\
\hline C-reactive protein & $0.14 \pm 0.17$ \\
\hline
\end{tabular}

\section{Results}

Table 2 shows the results of measurement regarding XOR and $X O$ activities, and these substrates. The XOR and XO activities (pmol/h/mL plasma) were 8.30-58.2 and 9.15-40.8, and XO/XOR value was $0.698-1.240$.

The relationship between $\mathrm{XOR}, \mathrm{XO}, \mathrm{XO} / \mathrm{XOR}$ and renal function (eGFR) is shown in Figure 1. A significantly positive correlation between eGFR and both XOR and XO was determined $(R=0.751$, $\mathrm{P}=0.0020$ and $\mathrm{R}=0.773, \mathrm{P}=0.0031$, respectively). On the other hand, $\mathrm{XO} / \mathrm{XOR}$ showed significantly negative correlation with eGFR ( $R=-0.614, P=0.0236)$, indicating that decreased renal function contributes to $\mathrm{XDH} \rightarrow \mathrm{XO}$ conversion.

Table 3 shows the results of simple regression analysis, and Table 4 shows that of multiple (forward stepwise) regression analysis between XOR, XO, XO/XOR and clinical data, in which clinical data were determined to be the explanatory variables, and $\mathrm{XOR}, \mathrm{XO}$ and $\mathrm{XO} / \mathrm{XOR}$ were the criterion variables. In the multiple regression analysis regarding $X O R$, eGFR and 
prescription of XOR inhibitor were adopted as an independent significant explanatory variable. Same variables (eGFR and prescription of XOR inhibitor) were also adopted independently in the multiple regression analysis regarding $X O$. These results suggest that low eGFR and usage of XOR inhibitor suppresses both $X O R$ and $X O$ activities. As to the multiple regression analysis regarding $\mathrm{XO} / \mathrm{XOR}$, selected explanatory variables were eGFR and xanthine.

Table 2: The results of measurement regarding xanthine oxidoreductase (XOR) and xanthine oxidase (XO) activities, and these substrates.

\begin{tabular}{|l|l|l|l|}
\hline & Mean & SD & Range \\
\hline XOR activity pmol/h/mL plasma & 23.1 & 15.9 & $8.30-58.2$ \\
\hline XO activity pmol/h/mL plasma & 19.4 & 10.0 & $9.15-40.8$ \\
\hline XO/XOR & 0.940 & 0.183 & $0.698-1.24$ \\
\hline Hypoxanthine $\mu \mathrm{M}$ & 2.27 & 2.02 & $0.30-7.09$ \\
\hline Xanthine $\mu \mathrm{M}$ & 5.60 & 7.57 & $0.11-26.4$ \\
\hline Uric acid $\mu \mathrm{M}$ & 220.8 & 74.4 & $23.5-350.0$ \\
\hline
\end{tabular}

Table 3: The simple regression between $X O R, X O, X O / X O R$ and clinical data, ${ }^{*} \mathrm{P}<0.05$.

\begin{tabular}{|c|c|c|c|c|c|c|}
\hline & \multicolumn{2}{|l|}{ XOR } & \multicolumn{2}{|l|}{ xo } & \multicolumn{2}{|c|}{ XO/XOR } \\
\hline & $\mathrm{R}$ & $\begin{array}{l}\mathrm{P}- \\
\text { value }\end{array}$ & $R$ & $\begin{array}{l}\mathrm{P}- \\
\text { value }\end{array}$ & $\mathrm{R}$ & $\begin{array}{l}\mathrm{P} \text { - } \\
\text { value }\end{array}$ \\
\hline $\begin{array}{l}\text { Estimated } \\
\text { glomerular } \\
\text { filtration rate }\end{array}$ & 0.751 & 0.0020 & $\begin{array}{l}0.73 \\
3\end{array}$ & $\begin{array}{l}0.003 \\
1^{*}\end{array}$ & $\begin{array}{l}-0.6 \\
14\end{array}$ & $\begin{array}{l}0.023 \\
6^{*}\end{array}$ \\
\hline Hypoxanthine & 0.003 & 0.9912 & $\begin{array}{l}-0.0 \\
60\end{array}$ & $\begin{array}{l}0.850 \\
5\end{array}$ & $\begin{array}{l}-0.1 \\
05\end{array}$ & $\begin{array}{l}0.738 \\
1\end{array}$ \\
\hline Xanthine & $\begin{array}{l}-0.61 \\
3\end{array}$ & 0.0239 & $\begin{array}{l}-0.6 \\
37\end{array}$ & $\begin{array}{l}0.017 \\
1^{*}\end{array}$ & $\begin{array}{l}0.71 \\
2\end{array}$ & $\begin{array}{l}0.004 \\
8^{*}\end{array}$ \\
\hline Uric acid & $\begin{array}{l}-0.56 \\
2\end{array}$ & 0.0443 & $\begin{array}{l}-0.5 \\
55\end{array}$ & $\begin{array}{l}0.047 \\
9^{*}\end{array}$ & $\begin{array}{l}0.34 \\
6\end{array}$ & $\begin{array}{l}0.253 \\
3\end{array}$ \\
\hline Age & $\begin{array}{l}-0.28 \\
8\end{array}$ & 0.3492 & $\begin{array}{l}-0.2 \\
79\end{array}$ & $\begin{array}{l}0.364 \\
4\end{array}$ & $\begin{array}{l}0.24 \\
6\end{array}$ & $\begin{array}{l}0.426 \\
1\end{array}$ \\
\hline Gender $($ male $=1)$ & $\begin{array}{l}-0.37 \\
5\end{array}$ & 0.2131 & $\begin{array}{l}-0.3 \\
96\end{array}$ & $\begin{array}{l}0.185 \\
5\end{array}$ & $\begin{array}{l}0.41 \\
8\end{array}$ & $\begin{array}{l}0.159 \\
7\end{array}$ \\
\hline BMI & 0.005 & 0.9864 & $\begin{array}{l}0.00 \\
3\end{array}$ & $\begin{array}{l}0.993 \\
1\end{array}$ & $\begin{array}{l}-0.0 \\
92\end{array}$ & $\begin{array}{l}0.771 \\
4\end{array}$ \\
\hline $\begin{array}{l}\text { History of } \\
\text { cardiovascular } \\
\text { disease }\end{array}$ & 0.665 & 0.0113 & $\begin{array}{l}0.64 \\
0\end{array}$ & $\begin{array}{l}0.016 \\
6^{*}\end{array}$ & $\begin{array}{l}-0.3 \\
93\end{array}$ & $\begin{array}{l}0.188 \\
6\end{array}$ \\
\hline $\begin{array}{l}\text { Antihypertensive } \\
\text { medication }\end{array}$ & $\begin{array}{l}-0.54 \\
5\end{array}$ & 0.0530 & $\begin{array}{l}-0.5 \\
54\end{array}$ & $\begin{array}{l}0.048 \\
5^{*}\end{array}$ & $\begin{array}{l}0.39 \\
1\end{array}$ & $\begin{array}{l}0.191 \\
9\end{array}$ \\
\hline $\begin{array}{l}\text { Usage of } \\
\text { erythrocyte- } \\
\text { stimulating factor }\end{array}$ & $\begin{array}{l}-0.26 \\
0\end{array}$ & 0.4008 & $\begin{array}{l}-0.2 \\
60\end{array}$ & $\begin{array}{l}0.401 \\
0\end{array}$ & $\begin{array}{l}0.22 \\
0\end{array}$ & $\begin{array}{l}0.478 \\
8\end{array}$ \\
\hline $\begin{array}{l}\text { Usage of } \\
\text { xanthine- } \\
\text { oxidoreductase } \\
\text { inhibitor }\end{array}$ & $\begin{array}{l}-0.74 \\
0\end{array}$ & 0.0027 & $\begin{array}{l}-0.7 \\
70\end{array}$ & $\begin{array}{l}0.001 \\
3^{*}\end{array}$ & $\begin{array}{l}0.59 \\
7\end{array}$ & $\begin{array}{l}0.029 \\
6^{*}\end{array}$ \\
\hline $\begin{array}{l}\text { Systolic blood } \\
\text { pressure }\end{array}$ & 0.096 & 0.7613 & $\begin{array}{l}0.14 \\
4\end{array}$ & $\begin{array}{l}0.647 \\
1\end{array}$ & $\begin{array}{l}-0.0 \\
50\end{array}$ & $\begin{array}{l}0.873 \\
0\end{array}$ \\
\hline
\end{tabular}

\begin{tabular}{|l|l|l|l|l|l|l|}
\hline $\begin{array}{l}\text { Diastolic blood } \\
\text { pressure }\end{array}$ & $\begin{array}{l}-0.26 \\
2\end{array}$ & 0.3955 & $\begin{array}{l}-0.1 \\
95\end{array}$ & $\begin{array}{l}0.532 \\
8\end{array}$ & $\begin{array}{l}0.22 \\
0\end{array}$ & $\begin{array}{l}0.478 \\
9\end{array}$ \\
\hline $\begin{array}{l}\text { C-reactive } \\
\text { protein }\end{array}$ & 0.109 & 0.7303 & $\begin{array}{l}0.16 \\
4\end{array}$ & $\begin{array}{l}0.600 \\
6\end{array}$ & $\begin{array}{l}0.00 \\
9\end{array}$ & $\begin{array}{l}0.976 \\
6\end{array}$ \\
\hline
\end{tabular}

Table 4: The multiple (stepwise) regression between $\mathrm{XOR}, \mathrm{XO}$, XO/XOR and clinical data, ${ }^{*} \mathrm{P}<0.05$.

\begin{tabular}{|c|c|c|c|c|c|c|}
\hline & \multicolumn{2}{|l|}{ XOR } & \multicolumn{2}{|l|}{ xo } & \multicolumn{2}{|c|}{ XO/XOR } \\
\hline & $\mathrm{R}$ & $\begin{array}{l}\mathrm{P}- \\
\text { value }\end{array}$ & $\mathrm{R}$ & $\begin{array}{l}\mathrm{P}- \\
\text { value }\end{array}$ & $\mathrm{R}$ & $\begin{array}{l}\mathrm{P} \text { - } \\
\text { value }\end{array}$ \\
\hline $\mathrm{R}$ of the test & $\begin{array}{l}0.86 \\
6\end{array}$ & 0.0010 & $\begin{array}{l}0.87 \\
4\end{array}$ & 0.0007 & $\begin{array}{l}0.81 \\
5\end{array}$ & 0.0043 \\
\hline $\begin{array}{l}\text { Estimated } \\
\text { glomerular } \\
\text { filtration rate }\end{array}$ & $\begin{array}{l}0.51 \\
4\end{array}$ & 0.0171 & $\begin{array}{l}0.47 \\
2\end{array}$ & 0.0226 & $\begin{array}{l}-0.42 \\
2\end{array}$ & 0.0556 \\
\hline Xanthine & ----- & ----- & ------ & ----- & $\begin{array}{l}0.56 \\
9\end{array}$ & 0.0152 \\
\hline Uric acid & ----- & ------ & ----- & ----- & ----- & ----- \\
\hline $\begin{array}{l}\text { History of } \\
\text { cardiovascular } \\
\text { disease }\end{array}$ & ----- & ------ & ------ & ----- & ------ & ------ \\
\hline $\begin{array}{l}\text { Antihypertensive } \\
\text { medication }\end{array}$ & --- & ----- & ------ & ----- & ------ & ------ \\
\hline $\begin{array}{l}\text { Usage of } \\
\text { xanthine- } \\
\text { oxidoreductase } \\
\text { inhibitor }\end{array}$ & $\begin{array}{l}-0.49 \\
3\end{array}$ & 0.0210 & $\begin{array}{l}-0.54 \\
2\end{array}$ & 0.0114 & ------ & ----- \\
\hline
\end{tabular}

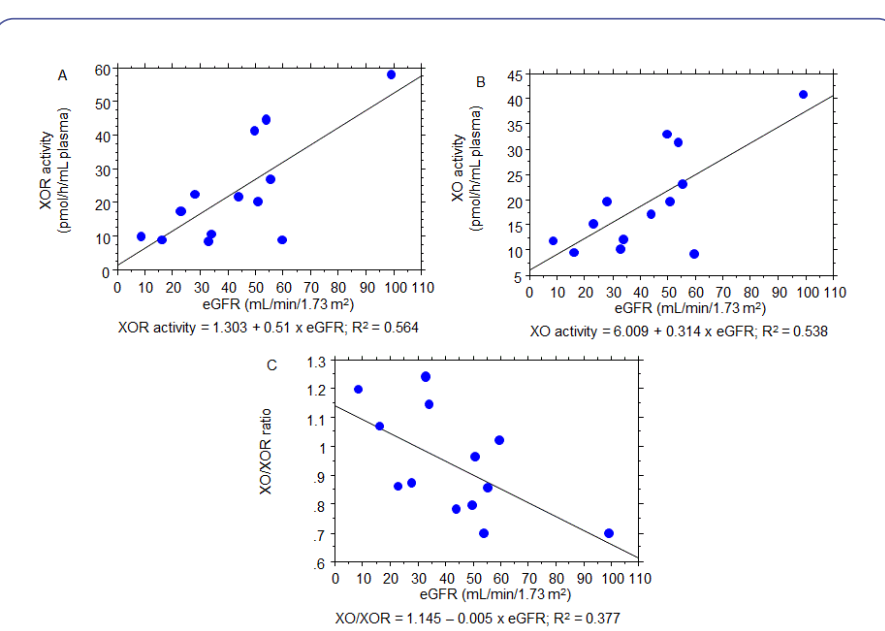

Figure 1: The relationship between estimated glomerular filtration rate and XOR activity (a), XO activity (b) and XO/XOR ratio (c). Estimated glomerular filtration rate shows a statistically significant positive correlation with XOR and XO activities, and a significant negative correlation with $\mathrm{XO} / \mathrm{XOR}$ ratio.

\section{Discussion}

In this report, we demonstrated that both XOR and XO activities are decreased, and $\mathrm{XDH} \rightarrow \mathrm{XO}$ conversion of plasma $X O R$ is accelerated, in accordance with renal dysfunction. To the best of our knowledge, this is the first report to reveal the 
relationship between renal function and XOR activity including conformation change, i.e. $\mathrm{XDH} \rightarrow \mathrm{XO}$ conversion.

XOR is a house-keeping enzyme and is recognized as a uratesynthesizer in a clinical medicine context. In the present study, we measured plasma XOR. The XOR state of plasma is thought to reflect that of capillary endothelial cells, since XOR is abundantly found in capillary endothelium and scarce in the endothelium of major vessels and endocardium [16]. The total area of the endothelium in humans is equal to that of 6 tennis courts, with most of the endothelium covering capillary vessels [17]. Capillary XOR plays a major role in redox maintenance of the whole body $[16,18]$ and takes part in various acute pathophysiologies, such as ischemia-reperfusion injury via $\mathrm{XDH}$ $\rightarrow \mathrm{XO}$ conversion $[9,19,20]$. Besides, $\mathrm{XDH} \rightarrow \mathrm{XO}$ conversion is essential for the lactation process, a fundamental function of mammals [21].

In this study, we demonstrated clear relationship between eGFR and both XOR and XO activity. Otaki et al. reported that both high and low XOR activity ( $\geq 120$ and $<33 \mathrm{pmol} / 100 \mu \mathrm{L} / \mathrm{h}$ ), measured using a combination of [13C2, 15N2] xanthine and liquid chromatography/triple quadrupole mass spectrometry, was related to poor outcome in patients with chronic heart disease [22]. Although the pathological significance by which abnormal XOR activity is unclear, too low XOR activity might reflect impaired endothelial viability.

XOR inhibitor has potential to reduce detrimental event among CKD patients [7,23], and the conserving function of the XOR inhibitor on endothelial cells is independent of the uratelowering effect [24]. About $85 \%$ of XOR exists as XDH in reductive condition such as cytosol of hepatic cell [25].

Not like XDH, XO utilizes molecular oxygen as electron acceptor and generates ROSs such as superoxide, which causes tissue injury including endothelial dysfunction. We have hypothesized that the ratio of XO over XOR increases in accordance with renal dysfunction in oxidative condition such as plasma. In this context, the progress of CKD among subjects with hyperuricemia [26-28] might be explained by the profound elevation of XO/XOR ratio.

In the multiple regression analysis regarding XO/XOR ratio, plasma xanthine level was selected as dependent explanatory variable. Although this result is interesting, the meaning of it is uncertain at the present.

In the present study, XO/XOR ratio exceeded 1 in patients with severely-impaired renal function. We suppose that this phenomenon reflects the irreversible modification of XOR, which could not be recovered by $N^{\prime} A D^{+}$treatment. XOR exhibits $\mathrm{XDH} \rightarrow \mathrm{XO}$ conversion not only by reversible disulfide bridge formation, but also by irreversible modification caused by proteases $[29,30]$. Such "irreversible" XO modification might cause this spurious elevation of XO/XOR ratio to over 1 .

In this study, we revealed a "decrease" of both XOR and XO activities in accordance with renal dysfunction. This result is in line with the report by Otaki et al., in which eGFR of "low XOR" group $(53 \pm 25 \mathrm{~mL} / \mathrm{min} / 1.73 \mathrm{~m} 2)$ was significantly lower than that of "normal XOR" group (68 $\pm 26 \mathrm{~mL} / \mathrm{min} / 1.73 \mathrm{~m} 2)$ [21]. On the other hand, Gondouin et al. reported the "increase" of XOR activity in accordance with renal dysfunction [31]. To measure XOR activity, Gondouin et al. used the "classical method", in which XOR activity is measured as urate level after administration of xanthine to the specimen. This classical method might well overestimate XOR activity because of elevated endogenous urate and other substances.

This study has several limitations. The first limitation is its cross-sectional nature: a prospective study is needed to prove the effect of the XOR inhibitor on XO/XOR ratio. The second is that the degree of endothelial function or vascular damage is not evaluated in this study. The third and perhaps most obvious limitation of this report is that the number of participants was small (13 participants). Studies with a larger subject population are warranted to allow more detail statistical analysis including comparison test between stratified groups and following posthoc test.

In conclusion, we demonstrated that $\mathrm{XOR}$ and $\mathrm{XO}$ activities are decreased, and $\mathrm{XDH} \rightarrow \mathrm{XO}$ conversion of plasma XOR is accelerated, in accordance with renal dysfunction. Clinical strategies targeting $\mathrm{XO} / \mathrm{XDH}$ modification should be encouraged in the future, for high XO/XOR ratio in advanced CKD patients might contribute to the elevation of OS.

\section{Acknowledgements}

We would like to thank Ms. Atsuko Hashimoto for her technical assistance regarding plasma preparation.

\section{References}

1. Go AS, Chertow GM, Fan D, McCulloch CE, Hsu CY (2004) Chronic kidney disease and the risks of death, cardiovascular events, and hospitalization. N Engl J Med 351: 1296-1305.

2. Nakayama $M$, Metoki $H$, Terawaki $H$, Ohkubo $T$, Kikuya $M$, et al. (2007) Kidney dysfunction as a risk factor for first symptomatic stroke events in a general Japanese population--the Ohasama study. Nephrol Dial Transplant 22: 1910-1915.

3. Himmelfarb J, Stenvinkel P, Ikizler TA, Hakim RM (2002) The elephant in uremia: oxidant stress as a unifying concept of cardiovascular disease in uremia. Kidney Int 62: 1524-1538.

4. Terawaki $H$, Yoshimura $K$, Hasegawa T, Matsuyama $\mathrm{Y}$, Negawa T, et al. (2004) Oxidative stress is enhanced in correlation with renal dysfunction: examination with the redox state of albumin. Kidney Int 66: 1988-1993.

5. Terawaki H, Takada Y, Era S, Funakoshi Y, Nakayama K, et al. (2010) The redox state of albumin and serious cardiovascular incidence in hemodialysis patients. Ther Apher Dial 14: 465-471.

6. Ciccone MM, Cortese F, Gesualdo M, Carbonara S, Zito A, et al. (2013) Dietary intake of carotenoids and their antioxidant and anti-inflammatory effects in cardiovascular care. Mediators Inflamm 2013: 782137.

7. Terawaki H, Nakayama M, Miyazawa E, Murata $Y$, Nakayama K, et al. (2013) Effect of allopurinol on cardiovascular incidence among hypertensive nephropathy patients: the Gonryo study. Clin Exp Nephrol 17: 549-553. 
8. Nishino T (1994) The conversion of xanthine dehydrogenase to xanthine oxidase and the role of the enzyme in reperfusion injury. J Biochem 116: 1-6.

9. Hille R, Nishino T (1995) Flavoprotein structure and mechanism. 4. Xanthine oxidase and xanthine dehydrogenase. FASEB J 9: 995-1003.

10. Sakuma S, Fujita J, Nakanishi M, Wada SI, Fujimoto Y (2008) Disulfide S-monoxides convert xanthine dehydrogenase into oxidase in rat liver cytosol more potently than their respective disulfides. Biol Pharm Bull 31: 1013-1016.

11. Houston M, Estevez A, Chumley P, Aslan M, Marklund, et al. (1999) Binding of xanthine oxidase to vascular endothelium. J Biol Chem 19: 4985-4994.

12. Newaz MA, Adeeb NN (1998) Detection of xanthine oxidase in human plasma. Med J Malaysia 53: 70-75.

13. Murase T, Nampei M, Oka M, Ashizawa N, Matsumoto $\mathrm{K}$, et al. (2016) Xanthine oxidoreductase activity assay in tissues using stable isotope-labeled substrate and liquid chromatography highresolution mass spectrometry. J Chromatogr B Analyt Technol Biomed Life Sci 1008: 189-197.

14. Levey AS, Stevens LA, Schmid CH, Zhang YL, Castro AF, et al. (2009) A new equation to estimate glomerular filtration rate. Ann Intern Med 150: 604-612.

15. Murase T, Nampei M, Oka M, Miyachi A, Nakamura T (2016) A highly sensitive assay of human plasma xanthine oxidoreductase activity using stable isotope-labeled xanthine and LC/TQMS. J Chromatograph. B 1039: 51-58.

16. Jarasch ED, Grund C, Bruder G, Heid HW, Keenan TW, et al. (1981) Localization of xanthine oxidase in mammary-gland epithelium and capillary endothelium. Cell 25: 67-82.

17. Higashi $Y$, Noma K, Yoshizumi M, Kihara Y (2009) Endothelial function and oxidative stress in cardiovascular diseases. Circ J 73: 411-418.

18. Matsuyama $\mathrm{Y}$, Hayashi $\mathrm{T}$, Terawaki $\mathrm{H}$, Negawa $\mathrm{T}$, Terada $\mathrm{T}$, et al. (2009) Human astrocytes and aortic endothelial cells actively convert the oxidized form of albumin to the reduced form: reduced albumin might participate in redox regulation of nerve and blood vessel systems. J Physiol Sci. 59: 207-215.

19. McCord JM (1985) Oxygen-derived free radicals in postischemic tissue injury. N Engl J Med 312: 159-163.

20. Saugstad OD (1988) Hypoxanthine as an indicator of hypoxia: its role in health and disease through free radical production. Pediatr Res 23: 143-150.
21. Vorbach C, Scriven A, Capecchi MR (2002) The housekeeping gene xanthine oxidoreductase is necessary for milk fat droplet enveloping and secretion: gene sharing in the lactating mammary gland. Genes Dev 16: 3223-3235.

22. Otaki Y, Watanabe T, Kinoshita D, Yokohama M, Takahashi T, et al. (2017) Association of plasma xanthine oxidoreductase activity with severity and clinical outcome in patients with chronic heart failure. Int J Caridiol 228: 151-157.

23. Goicoechea M, de Vinuesa SG, Verdalles U, Ruiz-Caro C, Ampuero $\mathrm{J}$, et al. (2010) Effect of allopurinol in chronic kidney disease progression and cardiovascular risk. Clin J Am Soc Nephrol 5: 1388-1393.

24. George J, Carr E, Davies J, Belch JJ, Struthers A (2006) High-dose allopurinol improves endothelial function by profoundly reducing vascular oxidative stress and not by lowering uric acid. Circulation 114: 2508-2516.

25. Sakuma S, Fujita J, Nakanishi M, Wada S, Fujimoto Y (2008) Disulfide s-monoxides convert xanthine dehydrogenase into oxidase in rat liver cytosol more potently than their respective disulfides. Biol Pharm Bull 31: 1013-1016.

26. Iseki K, Ikemiya Y, Inoue T, Iseki C, Kinjo K, et al. (2004) Significance of hyperuricemia as a risk factor for developing ESRD in a screened cohort. Am J Kidney Dis 44: 642-650.

27. Obermayr RP, Temml C, Gutjahr G, Knechtelsdorfer M, Oberbauer $R$, et al. (2008) Elevated uric acid increases the risk for kidney disease. J Am Soc Nephrol 19: 2407-2413.

28. Kawashima M, Wada K, Ohta H, Terawaki H, Aizawa Y (2011) Association between asymptomatic hyperuricemia and new-onset chronic kidney disease in Japanese male workers: a long-term retrospective cohort study. BMC Nephrol 12: 31.

29. Chung HY, Baek BS, Song SH, Kim MS, Huh JI, et al. (1997) Xanthine dehydrogenase/xanthine oxidase and oxidative stress. Age 20: 127-140.

30. Sarnesto A, Linder N, Raivio KO (1996) Organ distribution and molecular forms of human xanthine dehydrogenase/xanthine oxidase protein. Lab Invest. 74: 48-56.

31. Gondouin B, Jourde-Chiche N, Sallee M, Dou L, Cerini C, et al. (2015) Plasma xanthine oxidase activity is predictive of cardiovascular disease in patients with chronic kidney disease, independently of uric acid levels. Nephron 131: 167-174. 